\title{
REVITALISASI MANAJEMEN KOPERASI UNTUK MEWUJUDKAN KESEJAHTERAAN ANGGOTA KOPERASI (Studi Pada Dinas Koperasi dan UKM Kabupaten Muna)
}

\author{
${ }^{1}$ Sufiana, ${ }^{2}$ Syamsul Alam, ${ }^{2}$ Jopang \\ 'Universitas Halu Oleo, ${ }^{2}$ Jurusan Administrasi Publik Universitas Halu Oleo \\ sulfiana@gmail.com, jopang@uho.ac.id
}

\begin{abstract}
The purpose of this study was to determine the Implementation of Cooperative Revitalization in the Cooperative and SME Office of Muna Regency. The purpose of this study is to provide an overview of the implementation of the revitalization of cooperatives in the Muna Regency Cooperative and the UKM Office. This research was conducted at the Muna District Cooperative and the SME Institute. Data collection techniques used in this study are using primary data and secondary data. The data collected will be analyzed qualitatively.

The results of the research are based on the indicators of the Members' Meeting, the Audit Board, Managers, People, Interests, Rules and Structures, showing that the Revitalization of Cooperative Management to Achieve the Welfare of Cooperative Members in the Cooperative Office of Muna Regency has an important role for the survival of members and communities. While in the management of cooperatives to realize the welfare of cooperative members in the Muna Regency Cooperative Office, it runs in accordance with applicable standards.
\end{abstract}

Keywords: Cooperative; Management; Revitalization

\begin{abstract}
Abstrak
Tujuan penelitian ini adalah untuk mengetahui Implementasi Revitalisasi Koperasi di Kantor Koperasi dan UKM Kabupaten Muna. Tujuan dari penelitian ini adalah untuk memberikan gambaran tentang pelaksanaan revitalisasi koperasi di Koperasi Kabupaten Muna dan Kantor UKM. Penelitian ini dilakukan di Koperasi Kabupaten Muna dan Lembaga SME. Teknik pengumpulan data yang digunakan dalam penelitian ini adalah menggunakan data primer dan data sekunder. Data yang dikumpulkan akan dianalisis secara kualitatif.

Hasil penelitian berdasarkan indikatorRapat Anggota, Badan Pemeriksa, Manajer, Orang, Minat, Aturan, dan Struktur, menunjukkan bahwa Revitalisasi Manajemen Koperasi untuk Mewujudkan Kesejahteraan Anggota Koperasi di Kantor Koperasi Kabupaten Muna memiliki peran penting bagi kelangsungan hidup anggota dan masyarakat. Sedangkan dalam pengelolaan koperasi untuk mewujudkan kesejahteraan anggota koperasi di Kantor Koperasi Kabupaten Muna, itu berjalan sesuai dengan standar yang berlaku.
\end{abstract}

Kata kunci: Koperasi; Pengelolaan; Revitalisasi

\section{PENDAHULUAN}

Revitalisasi Koperasi atau kebangkitan kembali koperasi mengandung makna mengembalikan koperasi kepada jati dirinya, mengembalikan koperasi sebagai sokoguru perekonomian. Secara praktis, revitalisasi koperasi mencakup serangkaian kegiatan untuk mengupayakan dan meningkatkan eksistensi gerakan koperasi. Setidaknya agar koperasi yang tidak aktif menjadi aktif dan koperasi yang aktif menjadi koperasi yang lebih besar. Sehingga dengan demikian suatu koperasi dinyatakan dalam status tidak aktif manakala tidak mampu menyelenggarakan Rapat Anggaran Tahunan (RAT) berturut- turut dalam tiga tahun terakhir dan atau tidak melaksanakan kegiatan usaha untuk melayani anggota. 
Bagi koperasi aktif dengan serangkaian kegiatan revitalisasi koperasi, diharapkan dapat menjadi koperasi yang lebih baik dalam kinerja usaha.

Dalam rangka mengoptimalkan suatu organisasi dapat dilakukannya revitalisasi. Revitalisasi merupakan bentuk kesadaran akan pentingnya suatu organisasi bagi kehidupan bangsa dan rakyat Indonesia, sebagai bentuk rumusan harapan masa depan akan kondisi suatu organisasi serta sebagai kebijakan dan strategi besar dalam melakukan proses revitalisasi itu sendiri (Yunus, dkk., 2017).

Langkah- langkah revitalisasi yang perlu dilakukan oleh koperasi meliputi pembentukan tim revitalisasi internal koperasi yang selanjutnya bertugas mengidentifikasi kondisi koperasi, menyusun rencana strategi, menyusun rencana aksi. Tim revitalisasi internal koperasi dibentuk dengan melibatkan unsur- unsur pengurus koperasi, pengawas, karyawan dan anggota koperasi dengan mempertimbangkan kecakapan sumber daya manusia yang tersedia.

Adapun strategi yang dapat direkomendasikan oleh Tim Revitalisasi Internal koperasi dapat berubah antara lain yaitu Reorganisasi kepengurusan, rasionalisasi karyawan, optimalisasi aset- aset produktif, penjualan aset- aset non produktif, penagihan dan penjadwalan ulang (Rescheduling) pembiayaan bermasalah kerja sama usaha/ kemitran dan mobilitasi sumber permodalan koperasi. Strategi pengembangan usaha tersebut dilengkapi dengan rencana pengembangan usaha yang antara lain meliputi kelayakan aspek pasar dan pemasaran, kelayakan aspek produksi, kelayakan aspek manajemen dan kelayakan aspek keuangan.

Lebih lanjut perlu dijelaskan bahwa manajemen koperasi tidak didasarkan pada pemaksaan wewenang, melainkan melalui keterlibatan dan partisipasi. Para manajer profesional koperasi menggunakan metode yang sama seperti manajemen pada umumnya. Hanya saja nilai-nilai dan tujuan yang harus diperjuangkan metode itulah yang membuat manajemen koperasi unik dan berbeda dari manajemen lainnya. Fungsi utamanya adalah mengupayakan kepemimpinan koperasi bagi anggota dan pengurus terpilih di dalam pengembangan kebijakan dan strategi yang akan memberdayakan koperasi dalam mewujudkan cita-cita atau tujuannya.

Koperasi- Koperasi fungsional tumbuh dan berkembang dengan tendensi selalu maju, akan tetapi sifatnya tertutup dalam arti hanya berkisar pada dirinya sendiri dan anggotaanggotannya. Sifat tertutup tersebut disebabkan karena berbagai keadaan. Organisasinya disusun berdasarkan lingkungan tertentu, seperti kantor dan kesatuan. Di daerah pedesaan mungkin sudah agak terbuka dengan daerah kerja meliputi kecamatan atau kabupaten dengan menghimpun anggota dari berbagai jenis instansi. Usahanya yang dominan adalah simpan pinjam yang umumnya dibatasi hanya untuk kepentingan anggota. Ini memang suatu ketentuan yang dianut oleh Koperasi Simpan Pinjam hanya untuk melayani anggota dan tidak melayani bukan anggota, dia bukanlah bank yang bekerja untuk melayani umum.

Untuk menggembangkan Koperasi Konsumsi sifat tertutup harus diberi jalan untuk menjadi terbuka, dalam arti pemikiran dan langkah- langkah di dalam usahanya. Koperasi Konsumsi yang dimaksud juga bukan koperasi tertutup. Bentuk usaha dari Koperasi ini adalah penyelenggaran toko konsumsi yang melayani masyarakat secara terbuka. Berbeda dengan usaha simpan pinjam yang lebih ditujukan untuk anggota, maka toko konsumsi seperti itu justru harus masuk dalam lingkungan masyarakat luas untuk melayani anggota dan bukan anggota.

Secara sederhana, Koperasi yang menerima simpanan- simpanan dan deposito dari para anggotanya serta memberikan pinjaman bagi anggota yang sarna yang disebut KSP. Konflik kepentingan asumsikan bahwa kendala legalisasi tidak ada masalah bila KSP/USP diperbolehkan menghimpun dana dari masyarakat luas koperasi dapat diproyeksikan akan terjadi konflik kepentingan antara anggta dengan non anggota. Disisi lain non anggota sebagai investor di KSP juga berhak mendapatkan pelayanan yang maksimal atau memperoleh manfaat yang tinggi dari koperasi, bila tidak akan mau berpartisipasi di KSP/USP. Mereka akan memilih bank sebagai tempat menyimpan uangnya ataupun berinvestasi dengan badan usaha non koperasi KSP/USP. Belum lagi dikaitkan dengan misi pemerintah dimana KSP/USP diharapkan sebagai lembaga non bank ataupun lembaga keuangan mikro (LKM) yang mampu menghimpun dan menyalurkan dananya ke UKM. 
Vol 2 No 3 August-October 2019. pp.10-20. Journal PUBLICUHO Faculty of Social and Political Sciences Halu Oleo University, Kendari, Southeast Sulawesi, Indonesia. ISSN 2621-1351 (online), ISSN 2685-0729 (print) Open Access at: http://ojs.uho.ac.id/index.php/PUBLICUHO/index

Kepentingan tersebut akan mengalami benturan dilapangan manakalah kebeutuhan salah satu unsur tidak terpenuhi.

Oleh sebab itu, untuk meminimalkan biaya konflik mau tidak mau membutuhkan pengawasan yang ketat dan transparant dari pemerintah. Karena dengan demikianlah akan terbangun kepercayaan stakholders khususnya yang non anggota mau menginvestasikan modalnya ke KSP/USP dan terpilihnya harmonisasi kepentingan di KSP/USP. Tujuan koperasi yang terutama adalah untuk meningkatkan kesejahteraan dan memenuhi kebutuhan para anggotanya. Penyimpanan yang lain yaitu KSP membuka beberapa kantor cabang di kota-kota lain di luar domisili hukumnya meskipun tanpa atau belum adanya ijin operasional dari instansi vertikal yang berwenang maupun instansi setempat yang berwenang mengeluarkan perijinan dan melakukan pengawasan.

Keadaan tersebut menjadi pendorong bagi penulis untuk melakukan pengkajian melalui suatu penelitian dengan judul "Revitalisasi Manajemen Koperasi Untuk Mewujudkan Kesejahteraan Anggota Koperasi (Studi Pada Dinas Koperasi Kabupaten Muna)".

\section{TINJAUAN PUSTAKA}

\section{Konsep Revitalisasi}

Secara umum revitalisasi didefenisikan sebagai badan hukum koperasi yang kuat, mandiri dan tangguh serta berdaya saing untuk menghimpun dan menggerakan potensi ekonomi, sosial dan budaya sesuai dengan nilai- nilai dan prinsip koperasi. Sehingga dengan demikian, revitalisasi koperasi diarahkan untuk melakukan pembenahan aspek kelembagaan, organisasi, manajemen, dan sumber daya manusia berdasarkan nilai- nilai dan prinsip koperasi untuk menigkatkan kinerja usaha koperasi yang mencangkup aspek permodalan, produksi, teknologi informasi, pembiayaan dan pemasaran.

Revitalisasi adalah upaya untuk memvitalkan kembali yang dulunya pernah vital/hidup, akan tetapi kemudian mengalami kemunduran/degradasi. Revitalisasi mencakup perbaikan aspek fisik, aspek ekonomi dan aspek sosial. Pendekatan revitalisasi harus mampu mengenali dan memanfaatkan potensi lingkungan seperti sejarah, makna, keunikan lokasi dan citra tempat. (Danisworo, 2002).

Revitalisasi koperasi bertujuan memperkokoh kedudukan koperasi sebagai badan hukum yang sehat,kuat,mandiri dan tangguh untuk menghimpun dan menggerakkan potensi ekonomi sosial dan budaya sesuai dengan nilai dan prinsip koperasi. Sedangkan Sasaran revitalisasi koperasi adalah terwujudnya kelembagaan koperasi yang kuat, didukung oleh perangkat organisasi koperasi dan terwujudnya usaha koperasi yang sehat, mandiri, dan berdaya saing.

Revitalisasi sendiri bukan sesuatu yang hanya berorientasi pada penyelesaian keindahan fisik saja, tapi juga harus dilengkapi dengan peningkatan ekonomi masyarakatnya serta pengenalan budaya yang ada. Untuk melaksanakan revitalisasi perlu adanya keterlibatan masyarakat. Keterlibatan yang dimaksud bukan sekedar ikut serta untuk mendukung aspek formalitas yang memerlukan adanya partisipasi masyarakat, selain itu masyarakat yang terlibat tidak hanya masyarakat di lingkungan tersebut saja, tetapi masyarakat dalam arti luas (Laretna, 2002).

Dalam rangka mengoptimalkan suatu organisasi dapat dilakukannya revitalisasi. Revitalisasi merupakan bentuk kesadaran akan pentingnya suatu organisasi bagi kehidupan bangsa dan rakyat Indonesia, sebagai bentuk rumusan harapan masa depan akan kondisi suatu organisasi serta sebagai kebijakan dan strategi besar dalam melakukan proses revitalisasi itu sendiri (Yunus, dkk., 2017).

\section{Tahapan Revitalisasi}

Sebagai sebuah kegiatan yang sangat kompleks, revitalisasi terjadi melalui beberapa tahapan dan membutuhkan kurun waktu tertentu serta meliputi hal - hal sebagai berikut:

a) Aspek Fisik. Aspek Fisik atau Inteverensi fisik mengawali kegiatan fisik revitalisasi dan dilakukan secara bertahap meliputi perbaikan dan peningkatan kualitas dan kondisi fisik. Inteverensi fisik penting sehingga inteverensi fisik pun sudah semestinya memperhatikan konteks lingkungan dan perencanaan fisik tetap harus dilandasi pemikiran jangka panjang. 
b) Aspek Ekonomi. Aspek Ekonomi atau Rehabilitasi Ekonomi yaitu revitalisasi yang diawali dengan proses artefak urban, harus mendukung proses rehabilitasi kegiatan ekonomi. Dalam konteks revitalisasi perlu dikembangkan fungsi campuran yang bisa mendorong terjadinya aktifitas ekonomi dan sosial.

c) Aspek Sosial. Aspek Sosial atau Revitalisasi sosial/institusional adalah sebuah kawasan akan terukur bila mampu menciptakan lingkungan yang menarik (Interesting), jadi bukan sekedar membuat beautifulplace. Maksudnya kegiatan tersebut harus berdampak positif serta dapat meningkatkan dinamika dan kehidupan sosial masyarakat/ warga (Public realms).

Ada beberapa aspek lain yang berperan dalam revitalisasi yaitu; penggunaan peran teknologi informasi, khususnya dalam mengelola keterlibatan banyak pihak untuk menunjang kegiatan revitalisasi. Selain itu revitalisasi dapat ditinjau dari aspek keunikan lokasi dan tempat bersejarah atau revitalisasi dalam rangka mengubah citra suatu kawasan, dengan dukungan mekanisme kontrol/ pengendalian rencana revitalisasi mampu mengangkat isu- isu strategis kawasan, baik dalam bentuk kegiatan aktivitas.

Berdasarkan pendapat berbagai ahli tersebut di atas maka dapat disimpulkan bahwa revitalisasi adalah suatu proses atau cara dan perbuatan untuk menghidupkan kembali suatu hal yang sebelumnya terbedaya sehingga revitalisasi menjadikan sesuatu perbuatan untuk menjadi vital sedangkan vital mempunyai arti sempit penting atau angat diperlukan untuk kehidupan dan sebagainya. (Raka, S. 2012).

\section{Pengertian Koperasi}

Sebelum melanjutkan uraian tentang Koperasi indonesia, terlebih dahulu memahami arti kata koperasi. Kata koperasi berasal dari kata bahasa Latin cooperatioo yang berarti kerja sama atau bekerja sama. Cooperation dapat diartikan bekerja bersama-sama dan usaha bersama untuk kepentingan bersama. Secara umum koperasi sebagai perkumpulan orang yang secara sukarela mempersatukan diri untuk memperjuangkan peningkatan kesejahteraan ekonomi melalui pembentukan sebuah perusahaan yang dikelola secara demokratis.

Menurut Arifin dan Halomoan $(2001 ; 13)$ menyatakan bahwa Koperasi mengandung makna kerjasama yang artinya menolong satu sama lain yang berkaitan dengan fungis- fungsi koperasi, fungsi sosial, fungsi ekonomi dan fungsi etika. Sedangkan Menurut UndangUndang No. 25 Tahun 1992, menjelaskan bahwa koperasi adalah badan usaha yang beranggotakan orang perorang atau badan hukum koperasi dengan melandaskan kegiatan berdasarkan prinsip koperasi sekaligus sebagai gerakan ekonomi rakyat yang berdasar atas azas kekeluargaan. Selanjtunya menurut Sitio dan Tamba (2001) berpendapat bahwa dalam tujuan tersebut dikatakan bahwa koperasi memajukan kesejahteraan anggota pada khususnya dam masyarakat pada umumnya. Pernyataan ini mengandung arti bahwa, meningkatkan kesejahteraan anggota adalah menjadi program utama koperasi melalui pelayanan usaha. Jadi, pelayanan anggota merupakan prioritas utama dibandingkan dengan masyarakat umum. Adapun pengertian Koperasi menurut Ropke, John (2003:13) adalah sebagai badan usaha dengan kepemilikan dan pemakai jasa merupakan anggota koperasi itu sendiri serta pengawasan terhadap badan usaha tersebut harus dilakukan oleh mereka yang menggunakan jasa/pelayanan badan usaha itu. Menurut ILO dalam Revrisond Baswir, (2000:2) Koperasi adalah suatu perkumpulan orang bisanya yang memiliki kemampuan ekonomi yang terbatas yang melalui suatu bentuk organisasi perusahaan yang diawasi secara demokratis, masing- masing memberikan sumbangan yang setara terhadap modal yang diperlukan dan tersedia menanggung resiko serta menerima imbalan yang sesuai dengan usaha yang mereka lakukan.

Munker (2004:44) mendefenisikan koperasi sebagai organisasi tolong menolong yang menjalankan "urusniaga" secara perkumpulan yang berazaskan konsep tolong menolong. Aktivitas dalam urusniaga semata- mata bertujuan ekonomi, bukan sosial seperti yang dikandung gotong royong.

Terkhusus, Koperasi di Indonesia termuat dalam UU No. 25 tahun 1992 tentang perkoperasian yang menyebutkan bahwa koperasi adalah badan usaha yang beranggotakan orang- orang atau badan hukum koperasi dengan melandaskan 
Vol 2 No 3 August-October 2019. pp.10-20. Journal PUBLICUHO Faculty of Social and Political Sciences Halu Oleo University, Kendari, Southeast Sulawesi, Indonesia. ISSN 2621-1351 (online), ISSN 2685-0729 (print) Open Access at: http://ojs.uho.ac.id/index.php/PUBLICUHO/index

kegiatannya berdasarkan prinsip koperasi, sekaligus sebagai gerakan ekonomi rakyat yang didasarkan asas kekelvargaan.

Jadi dapat diartikan bahwa Koperasi merupakan kumpulan orang dan bukan kumpulan modal. Koperasi harus betul- betul mengabdi kepada kepentingan perikemanusian semata- mata dan bukan kepada kebendaan. Kerjasama dalam koperasi didasarkan pada rasa persamaan derajat dan kesadaran para anggotannya.

\section{Manajemen Koperasi}

Mendefenisikan bahwa Manajemen Koperasi diselenggarakan oleh orang-orang yang bertanggung jawab untuk mengelola koperasi, nilai-nilai dan kekayaannya. Mereka ini mengerahkan segala kemampuan kepemimpinannya dan memilih kebijakan untuk mengembangkan koperasi berdasarkan hasil latihan profesional perkoperasian. Sehingga dapat disimpulkan bahwa manajemen koperasi adalah kegiatan profesional yang dilakukan koperasi untuk membantu seluruh keanggotaan koperasi di dalam mencapai tujuannya. Fungsi utama dalam manjemen koperasi adalah mengupayakan kepemimpinan koperasi bagi anggota dan pengurus terpilih di dalam pengembangan kebijakan dan strategi yang akan memberdayakan koperasi dalam mewujudkan cita-cita atau tujuannya.

Menurut Prof. Ewell Paul Roy yang dikutip melalui galihpangestu 14. Wordpress.com bahwa manajemen koperasi melibatkan 4 (empat) unsur yaitu: anggota, pengurus, manajer dan karyawan. Manajemen Koperasi dalam lingkup keputusan memiliki unsur yang sebagai berikut (Sitio dan Tamba; 2001) yaitu: Rapat Anggota, Pengurus dan Badan Pemeriksa. Rapat Anggota merupakan unsur dalam manajemen koperasi karena koperasi merupakan badan usaha milik para anggotanya.

Pada Organisasi Koperasi kewajiban serta kekuasaannya masing- masing terlihat pada bagian berikut:

1. Rapat Anggota merupakan pemegang kuasa tertinggi dalam menetapkan kebijakan umum dibidang organisasi, manajemen dan usaha koperasi. Kebijakan yang sifatnya sangat strategis dirumuskan dan ditetapkan pada forum Rapat Anggota. Umumnya, Rapat Anggota diselenggarakan sekali setahun.

2. Pengurus sebagai unsur manajemen yang bertanggung jawab sebagai badan yang memimpin koperasi. Pengurus berkewajiban untuk melaksanakan garis- garis besar usaha yang telah ditentukan oleh Rapat Anggota dan tercantum dalam Anggaran Dasar maupun Anggaran Rumah Tangga Koperasi. Jadi dapat dikatakan bahwa pada dasarnya penguruslah yang menentukan garis- garis besar kebijaksanaan yang akan dikerjakan bersama bagi Koperasi Primer dan mungkin oleh manajer beserta para pegawainya bagi Koperasi Sekunder.

3. Badan Pemeriksa merupakan salah satu di antara alat- alat perlengkapan organisasi Koperasi disamping Rapat Anggota dan Pengurus. Badan Pemeriksa mempunyai tugas untuk melakukan pengawasan dan peemriksaan terhadap kehidupan Koperasi termasuk di dalamnya organisasi, usaha dan kebijaksanaan pengurus.

Di sinilah Manajemen koperasi menjadi sangat penting artinya untuk dapat meningkatkan kemajuan Koperasi di Indonesia. Pertama, spesialisasi dapat terjadi di dalam suatu usaha pelayanan kepada masyarakat. Artinya pembagian pekerjaan yang masing- masing dikerjakan oleh para spesialis. Kedua, spesialisasi dapat terjadi di antara usaha dan kegiatan- kegiatan dalam masyarakat. (Sari, AR.2013).

\section{Revitalisasi Manajemen Koperasi}

Kementerian Koperasi dan Usaha Kecil dan Menengah telah menetapkan Peraturan Menteri No. 25/Per/M.KUM/IX/2015 tentang revitalisas koperasi. Pertama untuk meningkatkan pera koperasi dalam mewujudkan kesejahteraan anggota khususnya dan masyarakat pada umumnya, koperasi memperkokoh kedudukannya sebagai wadah untuk menghimpun dan menggerakan potensi ekonomi, sosial dan budaya sesuai dengan nilai dan prinsip- prinsip koperasi, sehingga koperasi sebagai badan hukum mampu berperan menjalankan usaha yang sehat, kuat, mandiri dan tangguh. Kedua untuk meningkatkan kesadaran pengurus dan pengelola koperasi untuk melaksanakan langkah- langkah revitalisasi secara terencana, terpadu dan berkelanjutan. 
Revitalisasi Koperasi adalah serangkaian kegiatan yang diselenggarakan oleh koperasi dalam mengupayakan agar koperasi yang tidak aktif menjadi koperasi aktif dan koperasi aktif menjadi koperasi yang lebih besar.

Seluruh pelaksanaan langkah- langkah revitalisasi koperasi kemudian dituangkan menjadi dokumen yang disampaikan kepada Aparatur Pembina Koperasi untuk dijadikan dasar pemantauan revitalisasi koperasi adalah:

1) Koperasi Tidak Aktif yang gagal melakukan revitalisasi menjadi koperasi aktif, melakukan pembubaran atas keputusan rapat anggota.

2) Koperasi Aktif yang gagal melakukan revitalisasi menjadi koperasi yang lebih besar, melakukan perubahan rencana strategis dan atau rencana pengembangan usaha.

Jadi, Revitalisasi Koperasi merupakan bagian dari kebijakan reformasi koperasi total yang digulirkan oleh Kementrian Koperasi dan UKM. Hal ini ditegaskan oleh AAGN Puspayogya, Menteri Koperasi dan UKM bahwa merupakan suatu keharusan agar koperasi semakin mandiri, sehat dan profesional dan mampu bersaing (Farisma,IK 2016).

\section{Kesejahteraan Anggota Koperasi}

Kesejahteraan adalah suatu sistem yang terorganisasi dari layanan- layanan sosial dan lembaga- lembaga yang bermaksud untuk mencapai standar- standar kehidupan dan kesehatan yang memuaskan, serta hubungan- hubungan perorangan dan sosial yang memungkinkan dan menggembangkan segenap kemampuan dan meningkatkan kesejahteraan selaras dengan kebutuhan- kebutuhan masyarakat. Tujuan kesejahteraan adalah untuk menjamin kebutuhan ekonomi manusia, standar kesehatan dan kondisi kehidupan yang layak mendapatkan kesempatan yang sama dengan peningkatan derajat setinggi mungkin, kebebasan berfikir dan melakukan kegiatan tanpa gangguan sesuai dengan Hak Asasi Manusia (Walter A. Friedlander dalam Efendy, 2007). Menurut Setiadi (2003:9) mengatakan bahwa pencapaian peningkatan kesejahteraan adalah tujuan usaha yang bermanfaat dalam usaha koperasi serta merupakan karya kegiatan dalam rangka tanggung jawab moril dan sosial. Serta yang penting adalah mempertinggi taraf hidup anggotanya, meningkatkan produksi dan mewujudkan pendapatan yang adil dan kemakmuran yang merata dan koperasi wajib memiliki dan berlandaskan nilai- nilai menolong diri sendiri, bertanggung jawab kepada diri sendiri, demokrasi, persamaan, keadilan dan solidaritas. Dengan demikian, keberhasilan koperasi dalam mencapai tujuannya dapat diukur dari peningkatan kesejahteraan anggota. Kesejahteraan bermakna sangat luas dan juga bersifat relatif, karena ukuran sejahtera bagi seseorang dapat berbeda satu sama lain. Keberhasilan koperasi dalam meningkatkan kesejahteraan sosial ekonomi anggotanya akan lebih mudah diukur, apabila aktivitas ekonomi yang dilakukan oleh anggota dilakukan melalui koperasi.

Menurut Syahyuti (2006) Komponen Kelembagaan adalah :

1. Person. Orang-orang yang terlibat di dalam satu kelembagaan dapat diidentifikasi dengan jelas.

2. Kepentingan. Orang-orang tersebut sedang diikat oleh satu kepentingan/ tujuan, sehingga mereka terpaksa harus saling berinteraksi.

3. Aturan. Setiap kelembagaan mengembangkan seperangkat kesepakatan yang dipegang secara bersama, sehingga seseorang dapat menduga apa perilaku orang lain dalam lembaga tersebut.

4. Struktur. Setiap orang memiliki posisi dan peran, yang harus dijalankannya secara benar. Orang tidak bisa merubah-rubah posisinya dengan kemauan sendiri.

Dari definisi yang telah diuraikan di atas bahwa kesejahteraan anggota koperasi dapat dicapai jika anggota koperasi mempunyai peluang membiayai pendidikan keluarga, peluang memenuhi kebutuhan mengikuti kegiatan kursus keterampilan, tingkat kelancaran dan produktivitas usaha anggota, volume usaha dan pendapatan meningkat serta perkembangan pangsa pasar yang lebih meluas. 


\section{Kerangka Pikir}

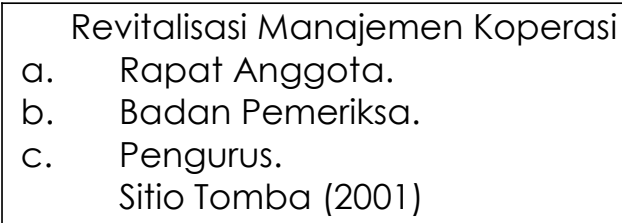

Gambar 1. Kerangka Pikir Penelitian

\section{Kesejahteraan}

Anggota Koperasi

a. Person.

b. Kepentingan.

c. Aturan.

d. Struktur.

Syahyuti (2006)

\section{METODE PENELITIAN}

\section{Jenis Penelitian}

Pendekatan penelitian ini menggunakan pendekatan kuantitatif. Metode pendekatan kuantitatif adalah penelitian dengan memperoleh data yang berbentuk angka atau data kualitatif yang berupa angka-angka kemudian dijelaskan secara baik (Sugiyono, 2014).

Penelitian ini dilaksanakan di Dinas Koperasi dan Usaha Kecil Menengah Kabupaten Muna, dengan mempertimbangkan bahwa Koperasi di Kabupaten Muna adalah salah satu unit pemberdaya ekonomi rakyat sebagai simpan pinjam yang kemudian berkembang dengan memiliki berbagai unit bisnis lain.

\section{Informan Penelitian}

Informan yang dibutuhkan dalam penelitian ini yaitu: Dinas Koperasi Kabupaten Muna yaitu, Kepala Dinas Koperasi, Sekretaris, Kepala Bidang Koperasi. Sedangkan Pengurus Koperasi yaitu, Ketua, Sekretaris, Bendahara dan Anggota Koperasi. (berjumlah 7 orang)

\section{Tekhnik Pengumpulan Data}

Teknik atau pengumpulan data yang digunakan dalam penelitian proposal ini terbagi atas:

1. Teknik Pengumpulan Data Primer, yaitu data yang diperoleh langsung dari lokasi penelitian untuk mencari kebenaran dan data yang lengkap dan berkaitan dengan masalah yang diteliti dalam penelitian pengumpulan data primer dilakukan dengan cara teknik wawancara atau observasi

2. Teknik Pengumpulan Data Sekunder yaitu teknik pengumpulan data yang dilakukan melalui studi perpustakaan yang berasal dari buku- buku atau sumber- sumber lain maupun instrument penelitian lain yang dapat membantu peneliti dalam pengumpulan data. Teknik ini dilakukan dengan cara yaitu: Studi dokumentasi, Studi keperpustakaan.

\section{Teknik Analisis Data}

Analisis data dalam penelitian kualitatif, dilakukan pada saat pengumpulan data berlangsung dan setelah selesai dilapangan. Teknik analisis data yang digunakan dalam penelitian ini adalah dengan menggunakan teknik analisis data kualitatif mengikuti konsep yang diberikan oleh Miles dan Hubersman dalam Sugiyono (2014: 428).

\section{HASIL DAN PEMBAHASAN}

\section{Revitalisasi Manajemen Koperasi Untuk Mewujudkan Kesejahteraan Anggota Koperasi Kabupaten Muna}

Revitalisasi merupakan badan hukum koperasi yang kuat, mandiri dan tangguh serta berdaya saing untuk menghimpun dan menggerakan potensi ekonomi, sosial dan budaya sesuai dengan nilai- nilai dan prinsip koperasi. Revitalisasi koperasi bertujuan mewujudkan kelembagaan koperasi yang kuat, didukung oleh perangkat organisasi koperasi dan terwujudnya usaha koperasi yang sehat, mandiri dan berdaya saing. Manajemen Koperasi dalam lingkup keputusan memiliki unsur yang sebagai berikut yaitu: Rapat Anggota, Pengurus dan Badan Pemeriksa. (Sitio dan Tamba; 2001). 
Dalam membangun dan mengembangkan kesejahteraan masyarakat dan anggota pada khususnya Dinas Koperasi dan UKM Kabupaten Muna telah memberikan pelayanan dengan semaksimal mungkin agar tercapai apa yang diharapkan bagi koperasi yang tidak aktif maupun koperasi yang aktif. Dengan tujuan menjadi salah satu dari usaha yang mengurus perusahaan rakyat yang dapat diselenggarakan atas dasar koperasi.

Berikut beberapa hasil wawancara peneliti dan informan berkaitan dengan Rapat Anggota, pengurus dan Badan Pemeriksa pada Dinas Koperasi dan UKM Kabupaten Muna menyatakan bahwa:

"Selama ini saya rasa dalam Dinas Koperasi dan UKM pada Rapat Anggota, Pengurus maupun Badan pemeriksa yang ada di dinas ini sudah baik, ini saya katakan sesuai dengan kinerja pegawai manakalah ada tugas kantor yang diberikan kepada mereka (Pegawai) dikerjakan dengan baik". (Wawancara Drs. Muh Syafei, 5 Januari 2019).

Ketika peneliti menanyakan sejauh ini dikabupaten muna ada berapa koperasi yang aktif dan yang tidak aktif dalam RAT?

"Sejauh ini koperasi dikabupaten muna yang aktif dalam RAT sebanyak 237 koperasi dan yang tidak aktif 97 koperasi. Kami sebagai instansi yang ditugaskan negara berupaya bekerja dan memberikan pelayanan dengan sebaik mungkin sesuai dengan bidangnya masing- masing". ( Wawancara Muh Syafei, 5 Januari 2019 ).

Berkaitan dengan hal ini pula ketika peneliti melakukan wawancara kepada Kepala Dinas Koperasi dan UKM Kabupaten Muna mengenai kendala koperasi yang aktif dan tidak aktif mengungkapkan bahwa:

\begin{abstract}
"Ketika koperasi itu dinyatakan tidak aktif yang menjadi faktor utama yaitu kurangnya dana ataupun suntikan dana dan pengurus tidak berhasil mengelola koperasi. Namun kebijakan dari kami mengadakan revitalisasi agar koperasi yang tidak aktif dapat diaktifkan kembali dan anggotannya dapat terlayani serta membina agar lebih maju". (Wawancara Drs. Muh Syafei, 5 Januari 2019).
\end{abstract}

Dari hasil wawancara diatas dapat disimpulkan bahwa kebijakan dari Dinas Koperasi dan UKM Kabupaten Muna bermaksud untuk mempermudah dan meningkatkan kesejahteraan anggota koperasi serta memperluas jangkauan pelayanan terhadap semua kebutuhan anggota dan masyarakat khususnya masyarakat kabupaten muna. Pengurus dan anggota harus memberikan pelayanan usaha simpan pinjam. Usaha simpan pinjam adalah menyediakan jasa peminjaman dan menyiapkan dana untuk anggota pada khususnya dan masyarakat pada umummnya bertujuan agar anggota mendapatkan pinjaman dana dengan mudah dan tidak rumit.

Dalam rangka menghasilkan kualitas kerja yang baik, pengurus dan anggota harus bekerja sesuai kemampaun, profesional, teliti dan bekerja sesuai bidang yang telah ditentukan. Dari hasil wawancara diatas dapat disimpulkan bahwa pemahaman mengenai revitalisasi koperasi sudah jelas karena kebijakan dari dinas ini memberikan petunjuk dan pemahaman sehingga pengurus dan anggota bisa bekerja sesuai bidang masing- masing memberikan pelayanan dan mudah tidak berbelit- belit.

\title{
Manajemen Koperasi
}

Manajemen Koperasi diartikan sebagai pengelolaan koperasi untuk mencapai tujuannya yaitu meningkatkan perekonomian masyarakat. Manajemen sebagai fungsionaris atau pemegang jabatan yang melakukan semuannya sedangkan koperasi sebagai suatu bentuk usaha bersama di antara orang- orang yang mempunyai kepentingankepentingan bersama yang diijalankan dan dikelola bersama berdasarkan asas kekeluargaan.

Kesejahteraan adalah suatu sistem yang terorganisasi dari layanan- layanan sosial dan 
Vol 2 No 3 August-October 2019. pp.10-20. Journal PUBLICUHO Faculty of Social and Political Sciences Halu Oleo University, Kendari, Southeast Sulawesi, Indonesia. ISSN 2621-1351 (online), ISSN 2685-0729 (print) Open Access at: http://ojs.uho.ac.id/index.php/PUBLICUHO/index

lembaga- lembaga yang bermaksud untuk mencapai standar- standar kehidupan dan kesehatan yang memuaskan, serta hubungan- hubungan perorangan dan sosial yang memungkinkan dan menggembangkan segenap kemampuan dan meningkatkan kesejahteraan selaras dengan kebutuhan- kebutuhan masyarakat.

Tujuan kesejahteraan adalah untuk menjamin kebutuhan ekonomi manusia, standar kesehatan dan kondisi kehidupan yang layak mendapatkan kesempatan yang sama dengan peningkatan derajat setinggi mungkin, kebebasan berfikir dan melakukan kegiatan tanpa gangguan sesuai dengan Hak Asasi Manusia. Dalam Kesejahteraan Anggota Koperasi ada 4 unsur yaitu sebagai berikut; Person, Kepentingan, Aturan dan Struktur Menurut Syahyuti (2006).

Berikut beberapa hasil wawancara peneliti dan informan berkaitan dengan Person, kepentingan, Aturan dan Sturktur pada Ketua Koperasi Wanita Bunga Mete Kabupaten Muna.

Berkaitan dengan hal ini pula, ketika peneliti melakukan wawancara kepada Ketua Koperasi Wanita Bunga Mete mengenai Badan Hukum dan Sturktur kepengurusan koperasi menyatakan bahwa:

"Setiap koperasi memiliki badan hukum dan semua Koperasi yang ada dikabupaten muna ini memiliki badan hukum dan Badan Hukum dari koperasi ini BH. No. 331/BH/XX1.2/111/2007". (Wawancara Wa Ode Tena, 9 Januari 2019).

Dari hasil wawancara dan observasi diatas dapat disimpulkan bahwa para pengurus koperasi wanita bunga mete bermaksud untuk mengembangkan usaha melalui unit simpan pinjam, unit usaha produksi dan unit warseda dan dapat berkembang bagi masyarakat.

Berikut wawancara peneliti dengan ketua pengurus koperasi wanita bunga mete mengenai kantor apakah milik koperasi atau salah satu pengurus menyatakan bahwa:

"Untuk sekarang ini kantor masih milik salah satu pengurus bisa dibilang masih pinjaman dan perjanjian pinjaman ada dan pembayaran tiap bulannya 2,5\%". (Wawancara Wa Ode Tena, 9 januari 2019).

Dari hasil wawancara dan observasi diatas dapat disimpulkan bahwa Untuk koperasi wanita bunga mete diketahui bahwa kantor koperasi ini masih berbentuk pinjaman dalam menjalankan usaha akan tetapi dalam keahlian dan keterampilan adalah hal yang lebih utama dan kepercayaan ketua pengurus koperasi wanita bunga mete kepada para karyawan atau anggota membuat semakin berkembang.

Dari hasil wawancara dan observasi diatas dapat disimpulkan bahwa Untuk koperasi wanita bunga mete diketahui bahwa kantor koperasi ini masih berbentuk pinjaman dalam menjalankan usaha akan tetapi dalam keahlian dan keterampilan adalah hal yang lebih utama dan kepercayaan ketua pengurus koperasi wanita bunga mete kepada para karyawan atau anggota membuat semakin berkembang.

Berikut wawancara peneliti dengan ketua koperasi wanita bunga mete mengenai kerja sama koperasi dengan pihak lain mengungkapkan bahwa:

"Untuk sekarang ini mengenai kerja sama koperasi kami dengan pihak lain belum ada belum". (Wawancara Wa Ode tena, 9 Januari 2019).

Ketika peneliti menanyakan tentang pendidikan pengurus koperasi dan pelatihan serta upaya pengurus koperasi dalam meningkatakan kesejahteraan anggota koperasi mengungkapkan bahwa:

"Karyawan atau anggota koperasi wanita bunga mete ini mengenai pendidikan SI dan tamatan SMA dan perjalanan selama dikoperasi ini selama saya kerja kurang lebih 3 tahun baik tidak ada kendala serta dengan pelatihan bagi pengurus belum pernah ada". (Wawancara Wa Ode Marsiana, 19 Maret 2019).

Dari hasil wawancara dan observasi diatas dapat disimpulkan bahwa tenaga pengurus koperasi wanita bunga mete adalah sebagian besar PNS dan sebagian tamatan SMA tetapi mereka mempunyai keahlian dibidang kepengurusan dan administrasi demi 
kesejahteraan anggota koperasi meskipun perkembangan koperasi masih sangat membutuhkan bantuan dari pihak lain.

Berikut wawancara peneliti dan anggota koperasi wanita bunga mete mengenai perencanaan dan pelaksanaan oleh koperasi mengatakan bahwa:

\begin{abstract}
"Sejauh ini kita berorientasi dengan kegiatan apa yang kita laksanakan dengan menjaga keutuhannya jadi kita tidak berpikir bahwa bagaimana agar yang kita laksanakan ini semakin bagus dan berkembang dan pelaksaanannya sesuai dengan tupoksi dan kewajiban masing-masing pengurus dan anggota". (Wawancara Wa Ode Marsiana, 9 Januari 2019).
\end{abstract}

Ketika peneliti menanyakan mengenai pelaporan RAT tiap tahunnya dan jumlah anggota serta modal awal koperasi dibentuk mengungkapkan bahwa:

"Ketika kami mengadakan RAT kami menghadirkan seluruh anggota dan kemudian kami memberikan laporan sesuai dengan apa yang kita laksanakan serta pelaporan RAT tiap tahunnya baik dan jumlah anggota semenjak koperasi ini ada 55 orang modal awal 50 juta". (Wawancara Wa Ode Marsiana, 9 Januari 2019)

Dari hasil wawancara dan observasi diatas dapat disimpulkan bahwa koperasi wanita bunga mete mengenai perencanaan, pelaksanaan dan pelaporan sudah baik atau tidak berbelit- belit dengan tujuan demi kesejahteraan anggota masyarakat.

\title{
KESIMPULAN
}

Berdasarkan hasil penelitian dan pembahasan pada bab sebelumnya, maka dapat ditarik kesimpulan sebagai berikut:

1. Pelaksanaan Revitalisasi Manajemen Koperasi untuk mewujudkan kesejahteraan anggota terdiri dari :

a) Melaksanakan pemberdayaan berupa pemberian bantuan modal dan memberikan bantuan fasilitas kepada para anggota guna mempermudah dan dapat memenuhi kehidupan sehari- hari mereka.

b) Mengadakan pemetaan- pemetaan bagi koperasi yang tidak aktif agar bisa aktif kembali dan bisa melayani anggotanya serta memenuhi segala kebutuhan masyarakatnya.

2. Pelaksanaan Manajemen Koperasi untuk mewujudkan kesejahteraan anggota koperasi yang ada pada Dinas Koperasi dan UKM Kabupaten Muna berjalan sesuai dengan standar yang berlaku. Namun dalam pelaksananannya terdapat beberapa faktor yang menjadi penghambat bagi para pengurus dan anggota koperasi dimana faktor penghambatnya yaitu:

a) Kurangnya modal.

b) Tidak ada kesadaran untuk mengembalikan pinjaman uang kepada KUD.

c) Regulasi perkoperasian.

d) Kurangnya pemahaman masyarakat terhadap KUD sehingga menjadikan KUD tidak berjalan dengan baik. Selain itu juga yang menjadi faktor pendorong yang membuat KUD bisa berkembang diantarannya SDM, tingkat pendidikan dan modal peralatan.

\section{SARAN}

Adapun saran yang disampaikan dalam hubungannya dengan penelitian ini adalah sebagai berikut:

1. Dalam pelaksanaan revitalisasi manajemen koperasi untuk mewujudkan kesejahteraan anggota koperasi maka perlu apresiasi dari pemerintah untuk bekerjasama dengan para pengurus dan anggota koperasi untuk memperbaiki seperti kurangnya modal, kurangnya kesadaran untuk mengembalikan pinjaman uang kepada KUD, regulasi perkoperasian dan kurangnya pemahaman masyarakat terhadap KUD agar koperasi yang ada di Kabupaten Muna bisa berkembang dan dapat memenuhi kebutuhan 
masyarakat;

2. Bagi masyarakat setempat perlu ada kesadaran dalam pengambilan modal sehingga KUD yang ada disekitaran tempat tinggal mereka bisa berkembang dan terus beroperasi serta dapat di manfaatkan dengan sebaik- baiknya.

\section{DAFTAR PUSTAKA}

Arifin, S dan Tamba Halomoan. 2001. Koperasi Teori dan Praktik. Jakarta : Erlangga.

Baswir Revrisond,. 2000. Koperasi Indonesia. Edisi Pertama. Yogakarta: BPFE UGM.

Danisworo. 2002. Pengertian Revitalisasi online .http://makalah dan skripsi.

Farisma, IK. 2016. Manajemn Koperasi. STIE Widya Praja Tanah Paser. Diakses pada 19 November 2018 pukul 10: 23 WITA.

Laretna. Adishakti. 2002. Revitalisasi Bukan Sekedar "Beautification". Urdi Vol.13, www.urdi.org (Urban and Reginal Development Institute).

Munker. 2004. Filsafat Pendidikan Al- Ghazali. Pustaka Setia : Yogyakarta.

Peraturan Undang- Undang. Nomor. 25 Tahun 1992: Tentang Fungsi dan Peranan Koperasi Simpan Pinjam Dan Unit Simpan Pinjam Koperasi; Jakarta.

Raka, S. 2012, Definisi Refitalisasi. Diambil dari http:// Makalah dan Skripsi.Blogspot.com. diakses pada 18 November 2018.

Ropke. John. 2003. Ekonomi Mikro. Penerbit UGM: Yogyakarta.

Sugiyono. 2008. Metode Penelitian Kuantitatif Kualitatif dan R \& D. Bandung: Alfabeta.

Syahyuti. 2006. Tinjauan Sosiologis Terhadap Konsep Kelembagaan Dan Upaya Membangun Rumusan Yang Lebih Operasional. Jurnal : Pusat Analisis Sosial Ekonomi dan Kebijakan Pertanian.

Sari, AR.2013. Manajemen Koperasi. http://makalah- Manajemen koperasis. Diakses pada 19 November 2018 pukul 12:54 WITA.

Setiadi, Nugroho J. 2003. Perilaku Konsumen Konsep dan Implikasi untuk Strategi Penelitian Pemasaran. Jakarta : Kencana.

Sitio dan Tamba. 2001. Koperasi Teori dan Praktik. Jakarta : Erlangga.

Yunus. dkk 2017. Desain Sistem Pembelajaran dalam Konteks Kurikulum

2013. Bandung : PT Refika Aditama. 